Article

\title{
Application of the Modified College Impact Model to Understand Chinese Engineering Undergraduates' Sustainability Consciousness
}

\author{
Qiudi Zhao ${ }^{1,+}$, Xianwei Liu ${ }^{2, *}+\oplus$, , Yonghong Ma ${ }^{1}$, Xiaoqi Zheng ${ }^{1}$, Miaomiao $\mathrm{Yu}^{3}$ \\ and Dongjiao $\mathrm{Wu}^{4}$ \\ 1 Institute of Higher Education, Beihang University, Beijing 100191, China; zhaoqd@buaa.edu.cn (Q.Z.) \\ myhong@buaa.edu.cn (Y.M.); zxq@buaa.edu.cn (X.Z.) \\ 2 Institute of Higher Education, Capital Research and Development Center for Engineering Education, \\ Beijing University of Technology, Beijing 100124, China \\ 3 Institute of Education Economics and Management, University of Science and Technology Beijing, \\ Beijing 100083, China; yumiaomiao@ustb.edu.cn \\ 4 School of Marxism, Beihang University, Beijing 100191, China; wudongjiao@buaa.edu.cn \\ * Correspondence: liuxianwei@bjut.edu.cn; Tel.: +86-010-6739-2673 \\ + The authors contributed equally to the study.
}

Received: 29 February 2020; Accepted: 23 March 2020; Published: 25 March 2020

\begin{abstract}
The college impact model provides a valuable framework for explaining various college student learning outcomes. However, few quantitative studies have examined the effectiveness of college impact model in explaining engineering undergraduates' sustainability consciousness, a critical learning outcome in engineering education. This study proposes a modified college impact model to test the structural links among curriculum experiences, sustainable agency beliefs, and engineering undergraduates' sustainability consciousness, and to explore the moderating effect of gender on the structural model. Data are collected from 1804 senior engineering students enrolled in five traditional engineering disciplines at 14 first-class engineering universities in China. Structural equation modeling was used for testing the research model. The results demonstrate that (1) curricular emphasis has a significant direct impact on all three dimensions of students' sustainability consciousness, while instructional practice has a significant direct influence on the sustainability knowingness dimension; (2) both curricular emphasis and instructional practice have a significant indirect influence on sustainability consciousness through the full or partial mediation of sustainable agency beliefs; and (3) gender moderates several paths in the structural model. Theoretical and practical implications are provided, and suggestions for future research are offered.
\end{abstract}

Keywords: college impact model; sustainability consciousness; curricular emphasis; instructional practice; sustainable agency beliefs; Chinese engineering undergraduates

\section{Introduction}

Given the crucial role of engineering and engineers in promotion of sustainable development, facilitating the development of engineering students' sustainability consciousness and preparing them to be capable of serving in sustainable development in their future careers have been prioritized by many engineering and technological universities, accreditation agencies, and professional societies around the world. For example, aligned with the Washington Accord, the Chinese Engineering Education Accreditation Association [1] has identified 12 criteria for engineering graduate outcomes, at least three of which explicitly regulate the skills, attitudes, and behaviors directly related to the sustainability engineering consciousness graduates need to possess, including Outcomes 3 ("an ability 
to design solutions for complex engineering problems and innovatively design systems, components or process that meet specific needs with societal, public health, safety, legal, cultural and environmental considerations"), 6 ("an ability to apply reasoning informed by contextual knowledge to assess societal, health, safety, legal and cultural issues and consequent responsibilities relevant to professional engineering practice"), and 7 ("an ability to understand and evaluate the impact of professional engineering solutions in environmental and societal contexts and demonstrate knowledge of and need for sustainable development").

Sustainability consciousness is regarded as a significant learning outcome in engineering education not only in China, but also in United States [2], United Kindom [3], Canada [4], Australia [5], Japan [6], and many other countries with developed engineering education systems. However, there is only a short history of research into the topic of incorporating sustainability and sustainable development issues into engineering education since the first Engineering Education in Sustainable Development Conference held in 2002 [7]. From a recent systematic and comprehensive literature review on this topic [8], the endeavors of engineering education researchers can be classified in two major lines of research. The first line or early research has mainly focused on introducing practices of institutions of higher education and engineering programs in implementing approaches to sustainability integration. The other line has shifted to evaluate the effectiveness of various curriculum and pedagogical methods toward sustainability integration. Nonetheless, these studies are limited in several ways. First, most existing research lacks a holistic and integrative view on students' sustainability learning outcomes, which should encompass the development in the cognitive, affective, and behavioral domains $[9,10]$. Second, most previous research has used small samples restricted to single engineering programs within single institutions. Third, previous research or case studies have been mainly conducted in Europe and North America, and little research exists on engineering students in developing countries or areas, such as China, which has the largest scale of engineering education around the world [11]. The last, but maybe most notable, limitation of previous studies is the lack of a comprehensive empirical framework used to explore the causal relationship between the introduction of sustainability into engineering education and engineering students' sustainability learning outcomes.

To address these limitations in existing studies, this study explicitly investigates the influences of two aspects of engineering students' curriculum experiences toward sustainability (i.e., curricular emphasis and instructional practice), sustainable agency beliefs, and gender on their sustainability consciousness (covering cognitive, attitudinal, and behavioral dimensions) based on a modified college impact model. The college impact model proposed by Terenzini and Reason [12] may be one of the most representative theoretical frameworks to explain the relationships among individual institutional factors influencing undergraduates' various skills and learning outcomes. It is necessary to study engineering undergraduates' sustainability consciousness by including sustainable agency beliefs in the college impact model because previous studies have recommended that engineering undergraduates be the agents of change, and they will be influenced by the sustainable problems that are rooted in current human activities $[13,14]$. Moreover, the moderation role of gender on the relationship between engineering students' college experiences and several learning outcomes (e.g., contextual awareness, design skills, and communication skills) have been tested in the United States [15,16]. However, there is still a need to further investigate the gender gap in the relationships among college experiences and sustainability learning outcomes [17].

Therefore, the main aim of this study is to utilize a modified college impact model to (1) test the impacts of two aspects of curriculum experiences (i.e., curricular emphasis and instructional practice) on engineering undergraduates' sustainability consciousness; (2) examine the mediating effect of sustainable agency beliefs in the relationship between curriculum experiences and engineering undergraduates' sustainability consciousness; and (3) explore the moderating role of gender on the relationships among curriculum experiences, sustainable agency beliefs, and engineering undergraduates' sustainability consciousness. To our knowledge, this is the first study employing a college impact model to evaluate students' sustainability learning outcomes. The findings of the 
current study will contribute to expanding the application areas of the college impact model in explaining sustainability learning outcomes and strengthen its content by incorporating sustainable agency beliefs. Moreover, with a thorough understanding of factors influence the sustainability consciousness of undergraduates in traditional engineering disciplines, our study can offer practical insight for the reform and development of engineering education in China in the context of engineering professional accreditation.

\section{Theoretical Background and Research Hypotheses}

\subsection{Modified College Impact Model}

After reviewing three decades of research on study outcomes of college students, Terenzini and Reason [12] developed the college impact model as a refinement and extension of Astin's [18] input-environment-output model. The college impact model illustrates the influence of (1) background characteristics and (2) college experiences, including organizational and program context and peer environment, on student outcomes. The basic premise of the college impact model is that students' background characteristics shape various aspects of their experiences within organizational and program contexts (e.g., organizational and program characteristics, structures, practices, policies, and faculty cultures) and, in turn, experiences within peer environments (e.g., curricular, classroom, and out-of-class experiences), which directly relate to learning outcomes (e.g., cognitive development, psychosocial and attitudinal change, and persistence). Several subsequent studies have provided empirical support for the utility of the college impact model since its proposal $[19,20]$. Focusing on the engineering context, several recent surveys performed in the United States have contributed to understand the relationship between college impact model components and engineering undergraduates' core learning outcomes recognized by the Engineer of 2020 report [21], such as contextual competence, fundamental skills, design skills [22], engineering leadership [23,24], interdisciplinary competence [25], teamwork skills, communication skills [24], and ethical development [26]. Following these pioneering studies, it is appropriate to employ the college impact model in the current study to effectively understand sustainability consciousness, which is also deemed an increasingly vital consideration for engineering education around the world [27].

The term "sustainability consciousness" was proposed and defined by a Swedish research team based on the extension of psychological research on environmental consciousness [10]. The group of researchers defined sustainability consciousness as a set of knowingness, attitudes, and behaviors regarding the three dimensions (environment, society, and economy) of sustainable development [28]. As a complex cognitive, affective, and behavioral learning outcome, the formation of sustainability consciousness is the result of interactions among educational, motivational, cultural, and other personal factors [29]. Bandura [30], in explaining the agentic aspects of social-cognitive theory, posited that individuals are not passively reactive to external educational influences, but they are proactive and self-reflective learners and agents. As a central theme of social-cognitive theory, agency beliefs are critical for engineering students' sustainability literacy development. Several recent studies have pointed out that engineering students' participation and learning in sustainability are fostered when they believe engineering has a chance to advance the world as a more sustainable place [31].

College impact scholars have repeatedly asserted that college experiences can support students' psychosocial, emotional, and motivational development [32-34], which in turn leads to a variety of capacities and literacy development. Astin [35] suggested that the college experience "must elicit sufficient student effort" (p. 522), which largely relies on "how motivated the student is" (p. 522). However, there remains a demand for more clear evidence regarding the possible motivational and psychosocial processes that underlie students' college experiences and their capacity or literacy [36]. Although the college impact model has been proven to be a more comprehensive framework for explaining students' outcomes, it may benefit from reasonable revision or expansion that makes it suitable to various outcomes about literacy and capacity development within different contexts. From 
the agentic socio-cognitive perspective, students become both "products" and "producers" of their learning environment $[37,38]$. In this sense, curriculum practices are important educational resources for aiding students in achieving learning outcomes, but this does not mean that the possession of certain curriculum experiences always leads to expected outcomes. Based on these perspectives, this study was designed to incorporate sustainable agency beliefs into a college impact model as a psychological mediator between learning and outcomes. In addition, with a sociocultural perspective on learning, some researchers further explore the differential relationship between engineering students' college experiences and their learning outcomes by their background characteristics (e.g., race, ethnicity, and gender) $[15,16,39,40]$. Therefore, we also operate gender as a moderating factor in the extended college impact model. Based on the extended college impact model, the research framework of the current study is shown in Figure 1.

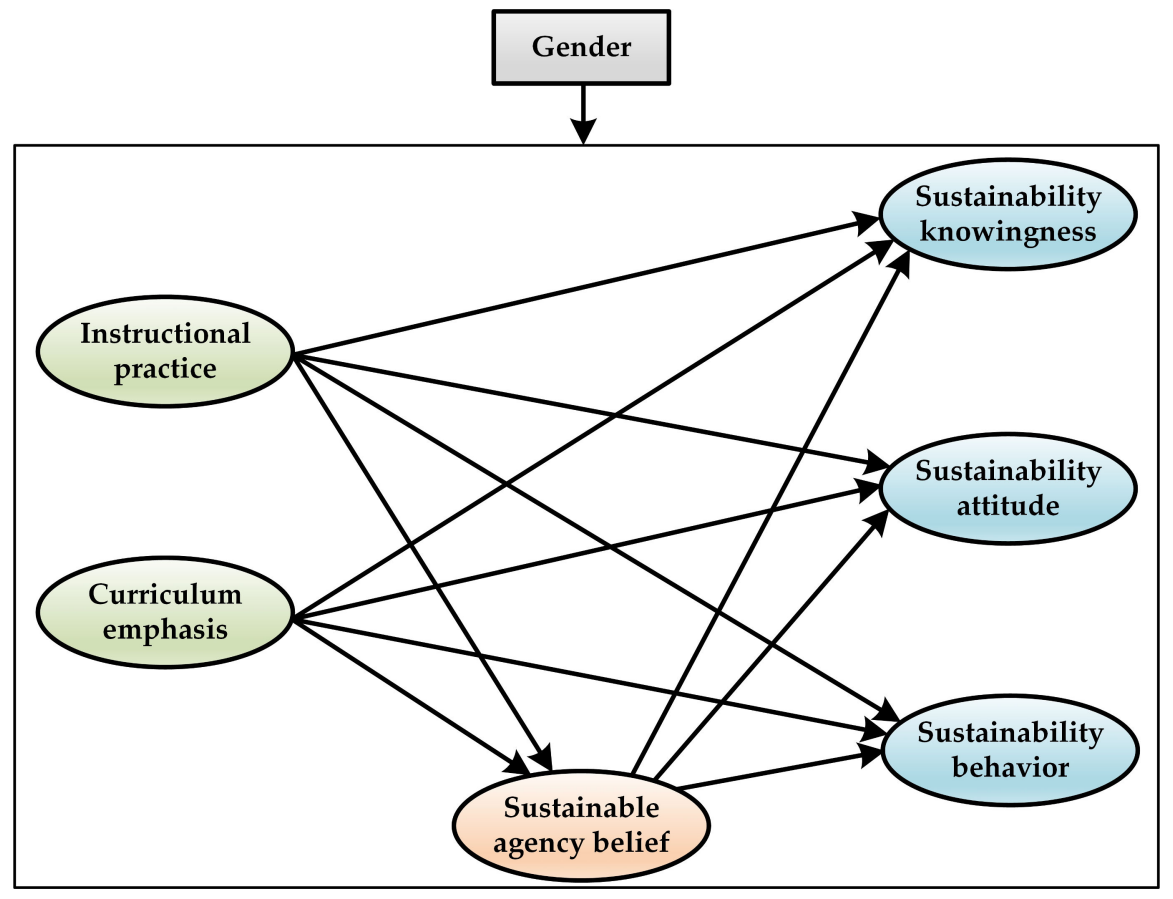

Figure 1. Research framework.

\subsection{Curriculum Experiences and Sustainability Consciousness}

Curriculum experts pointed out that learning outcomes should be one of the first considerations in the construction of a curriculum [41]. According to the college impact model, two aspects of student curriculum experiences in college, including experiences of curricular emphasis and instructional practice, might affect students' learning outcomes. For several decades, universities have been involved in integrating sustainability and sustainable development issues into engineering curriculum. As a response, a sizable body of literature has documented the incorporation cases and summarized the common approaches for diffusion and teaching of sustainable development in engineering education around the world $[8,42,43]$.

Previous empirical studies have shown how curricular emphasis toward sustainability can have a positive influence on the knowledge and attitude components of the sustainability consciousness of undergraduates. For example, at five public universities in Malaysia, Shing et al. [41] revealed that compulsory courses specifically related to sustainability exert the highest influence on chemical engineering undergraduates' sustainability interest and knowledge compared to any other types of courses. At the University of Toronto, Kennedy et al. [44] investigated 102 students and showed that the implementation of several environmental and water resource engineering courses increased students' environmental awareness. Kuo and Jackson [45] employed the New Ecological Paradigm (NEP) scale to assess changes in student sustainability attitudes before and after an introductory environmental 
studies course in an engineering university, and the results demonstrated that, although engineering students scored lower on the NEP than non-engineering students, the improvement in engineering students' scores was statistically significant after taking this environmental course. Bielefeldt [46] reported that the early emphasis of sustainability in an introductory course for civil and environmental engineering students influences their sustainability knowledge and attitudes. Tang [47] found that a sustainable development course provided in Curtin University Malaysia yielded positive effects on students' sustainability beliefs, attitudes, and behavioral intentions. In a recent survey of 539 students at Indiana University, Pizmony-Levy and Michel [48] demonstrated that the opportunity to learn about sustainability and environmental issues, an indicator of curricular experience, has positive and significant effects on undergraduates' pro-environmental attitudes and behaviors.

Curriculum is not limited to "what is taught" (i.e., course emphasis), but also includes "how should it be taught?" (i.e., instructional practice). The existing literature has identified the presence of certain types of pedagogies, instructional approaches, and strategies to better deliver sustainability content in courses and facilitate students' sustainability consciousness, such as student-centered instruction, project-based education, multidisciplinary and transdisciplinary approaches, and an active-learning pedagogical approach [49]. According to the constructivism learning theory [50], teaching sustainability is a matter of not only simply transmitting sustainability-related issues, contents, or facts, but also encouraging engineering students in active learning, constructing sustainability knowledge on the basis of their previous experiences and what they already know. Within the engineering education context, for instance, by using the concept map technique, Segalàs et al. [51] found that a more constructive, active-learning and community-oriented method applied in courses could increase engineering students' general knowledge of sustainability across three European universities. Similarly, Jollands and Parthasarathy [52] discovered that project-based learning as a promising approach for promoting sustainability education significantly improved the understanding of sustainability among chemical engineering students at the Royal Melbourne Institute of Technology, Australia. Yusof et al. [53] revealed that cooperative problem-based learning positively enhanced first-year engineering students' sustainable behaviors.

Although previous studies have not tackled experiences of curricular emphasis and instructional practice simultaneously, they have supported that various curricular and instructional opportunities toward sustainability should be surveyed to understand engineering undergraduates' sustainability consciousness enhancement. Tang [47] claimed that "the information which the respondents received from the course and additional efforts made in its delivery was expected to influence the respondents' beliefs concerning sustainability" (p. 461), which may eventually result in the formation of consciousness demonstrating sustainability traits. In line with the significance of curriculum experiences as suggested by the college impact model, current research attempts to extend this research on the promotion of engineering undergraduates' sustainability consciousness to evaluate the relative importance of two aspects of students' formal curriculum experiences. We therefore posit the following hypothesis:

H1a: Curricular emphasis has a significant positive influence on the three aspects of sustainability consciousness, namely, sustainability knowingness, attitudes, and behaviors.

H1b: Instructional practice has a significant positive influence on the three aspects of sustainability consciousness, namely, sustainability knowingness, attitudes, and behaviors.

\subsection{Mediating Role of Sustainable Agency Beliefs}

Agency beliefs involve individuals believing that they have the capacity to intentionally choose, implement, and control their own behaviors to acquire expected outcomes; it is a central concept in the theory of social-cognitive theory presented by Bandura [37]. Within the engineering education context, scholars [54-56] asserted that students' engineering agency beliefs involve how students see and think about engineering as a way to better the world, and proposed the concept and measurement of global agency, which involves students' beliefs in the capacity of engineering to have a beneficial impact on 
the world in a global sense. Following this view, sustainable agency beliefs are used here to indicate a student's perception of the ability of engineering to promote the sustainable development of the world because sustainable development involves addressing complex global problems in essence.

It has been suggested that agency beliefs can enhance individual's social responsibility sense, social consciousness, and social action [57]. Studies such as that conducted by Sampaio et al. [58] have shown that a high level of agency beliefs can result in more sustainability actions. In addition, based on a representative sample of engineering undergraduates in the United States, a series of studies have systematically measured agency belief, awareness, literacy, and action to address sustainable development issues and have examined the effect of agency beliefs on the sustainability-related career outcome expectations of students $[31,54,56,59,60]$.

According to previous research, the use of certain types of instructional and pedagogical practices foster the development of sustainability competencies (e.g., systems thinking, interdisciplinary work, and critical and creative thinking) $[49,61]$, which are critical to the creation of active change agents with empowered global responsibility and to the development of individuals' sustainability consciousness [62]. To date, only a few studies have shed light on the understanding of the curriculum experiences associated with sustainable agency beliefs in the context of engineering education. For example, a longitudinal case study by Godwin and Potvin [63] described how high school experiences helped a young woman build her agency beliefs and select an engineering major in college, while her experiences of engineering education weaken the agency beliefs she built and impelled her to quit engineering after her first year in college. Baugher et al. [64] further revealed that international service learning through formal curricular experiences was closely correlated with engineering students' agency beliefs.

Based on the modified college impact model and existing empirical evidence, we argue that the curricular emphasis and instructional practice toward sustainability may first influence students' sustainable agency beliefs and then enhance their sustainable consciousness. Therefore, the following hypotheses are developed:

H2a: Sustainable agency beliefs mediate the relationship between curricular emphases and aspects of sustainability consciousness.

H2b: Sustainable agency beliefs mediate the relationship between instructional practice and aspects of sustainability consciousness.

\subsection{Moderating Role of Gender}

The male domination of engineering fields and numerical unbalance may lead to exclude females from the "old boys' networks" [65], and result in the women's lack of educational resources and support in traditional engineering education areas as a result of the existing gender stereotypes [66]. In this sense, women are more likely than men to need agency beliefs to achieve expected learning outcomes [63], especially in the engineering context. Integration of sustainability in curriculum might be an important way to broaden females' engagement and diminish the gender gap in engineering education. In other words, women students may benefit psychologically and behaviorally more than men from education for sustainability [67]. For example, Klotz and colleagues [27] revealed that sustainability topics in engineering education raise females' interest in engineering, and female engineering students also exhibit more interest in addressing sustainability issues in their future careers than their male engineering peers. Existing literature has also demonstrated that girls show greater sustainability consciousness, that is, acquire more sustainability knowledge, attitudes, and behavior through education for sustainability [17]. However, to the best of our knowledge, there has not been a direct test for gender differences in the relationship among educational and psychological factors and sustainability consciousness.

The college impact model emphasized the interaction between individual factors and college experiences on students' learning outcomes. Consistent with previous research [33], sustainability 
consciousness as a critical learning outcome of engineering students might vary according to students' gender, particularly regarding different experiences, motivation, values, self-efficacies, self-concepts, interests, and eventual participation in the sustainability learning process. Thus, female and male undergraduates who attend the same courses and are exposed to similar instructional practices in their engineering programs may nonetheless have difference in sustainability consciousness due to the difference in how they perceive and value certain topics and pedagogical approaches utilized in their classroom. The present study designs to test the impact of differences in gender on the link between curriculum experiences and sustainability consciousness with sustainable agency beliefs as a mediating variable because gender has been repeatedly emphasized as a critical consideration in engineering education and sustainable education literature $[68,69]$. Hence, the following hypotheses are suggested:

H3: Gender moderates the relationships among curricular experiences, instructional practices, sustainable agency beliefs, and sustainability consciousness.

\section{Methodology}

\subsection{Sample}

Data were collected from 14 first-class engineering and technology universities located in Beijing, Shanghai, Tianjin, Nanjing, Xi'an, and Wuhan in China. This research targeted five engineering disciplines (i.e., civil, electrical, mechanical, chemical, and materials engineering) because they represent the most traditionally and commonly offered engineering disciplines in colleges and universities throughout China. With the assistance of the student activities advisors of each targeted engineering discipline, survey questionnaires were sent to 2100 engineering students at the beginning of their fourth year of undergraduate study in October 2019. Before giving consent, all participants were informed that the purpose of the survey, as well as the anonymity and voluntariness of their participation. 1987 questionnaires were collected in total. After eliminating 183 invalid questionnaires, 1804 responses were finally utilized for statistical analysis. The characteristics of the survey respondents are summarized in Table 1.

Table 1. Characteristics of survey respondents.

\begin{tabular}{|c|c|c|c|}
\hline Characteristic & Categories & Number of Respondents & Percentage $(\%)$ \\
\hline \multirow{5}{*}{ Engineering discipline } & civil engineering & 222 & 12.3 \\
\hline & electrical engineering & 267 & 14.8 \\
\hline & mechanical engineering & 685 & 38.0 \\
\hline & chemical engineering & 188 & 10.4 \\
\hline & materials engineering & 442 & 24.5 \\
\hline \multirow{2}{*}{ Gender } & Female & 589 & 32.6 \\
\hline & Male & 1215 & 67.4 \\
\hline \multirow{2}{*}{ Ethnicity } & Han & 1706 & 94.6 \\
\hline & Other & 98 & 5.4 \\
\hline \multirow{2}{*}{ Area of family residence } & Urban & 946 & 52.4 \\
\hline & Rural & 858 & 47.6 \\
\hline \multirow{2}{*}{$\begin{array}{l}\text { First-generation } \\
\text { university student }\end{array}$} & Yes & 530 & 29.4 \\
\hline & No & 1274 & 70.6 \\
\hline
\end{tabular}




\subsection{Measurement}

The questionnaire was divided into two sections. Section one requested participants to report their background characteristics, including engineering discipline, gender, ethnicity, area of family residence, and status as first-generation university student. Part two was the measurement of variables in our research model. All measures were adopted and revised from previous literature utilizing a Likert type scale.

Eight items were used to measure two sets of curriculum experience variables, namely, curricular emphasis and instructional practice. Four items of the curricular emphasis scale derived from Lattuca et al. [25] were revised to assess how much sustainability-related knowledge and skills were emphasized in engineering students' formal courses, with answers ranging from "little emphasis" (1) to "very strong" (5). For instructional practice, four items were adapted from the student-centered teaching scales of Lattuca et al. [25] and Michel [70]. We asked engineering students to answer how often they experienced different student-centered teaching techniques for sustainability throughout their engineering programs in formal courses using a five-point Likert scale that ranges from "never" (1) to "always" (5). The items were modified to fit the objectives of this study. For example, "Explained new concepts by linking them to what students already know" was changed to "Explained sustainability-related concepts by linking them to what students already know".

A four-item sustainable agency belief scale revised from the global agency beliefs scale of Godwin et al. [56] was used to evaluate engineering students' beliefs about the potential for engineering to contribute to the promotion of sustainable development. Responses were indicated on a five-point Likert scale ranging from "strongly disagree" (1) to "strongly agree" (5). The items were modified to apply to the context of engineering education. For example, "a country needs science and technology to become developed" was changed to "A country needs engineering to become developed".

A 15-item scale derived from the Chinese version sustainability consciousness scale developed by Olsson et al. [71], and was used to measure engineering students' sustainability knowingness (five items), sustainability attitude (five items), and sustainability behavior (five items). Each subscale covers three dimensions of sustainable development (i.e., environment, society, and economy). The participants were asked to report the degree to which they agreed with the statements regarding sustainability, and each of the items was rated on a five-point Likert-type scale ranging from "strongly disagree" (1) to "strongly agree" (5).

Additionally, to examine the moderating role of gender on the hypothesized paths, we coded it as a dummy variable in the study $(0=$ female, $1=$ male $)$.

Table 2 shows the mean, standard deviation, skewness, and kurtosis of the scale items. The mean of the items ranged from 3.915 to 4.528 , and their standard deviation ranged from 0.656 to 0.972 . Moreover, the absolute values of skewness were less than 3 (from 0.424 to 1.903), and the absolute values of kurtosis were lower than 10 (from 0.061 to 6.319), implying that the survey data satisfied the criteria of a multivariate normal distribution and that further statistical analyses could be performed [72].

Table 2. Questionnaire items and results of descriptive statistics.

\begin{tabular}{|c|c|c|c|c|}
\hline Variables/Measurement Items & Mean & SD & Skewness & Kurtosis \\
\hline \multicolumn{5}{|l|}{ Curricular emphasis (CE) } \\
\hline $\begin{array}{l}\text { CE1: Generating and evaluating ideas about how to } \\
\text { solve an engineering problem in a sustainable way }\end{array}$ & 4.169 & 0.697 & -0.783 & 1.546 \\
\hline $\begin{array}{l}\text { CE2: The value of gender, racial/ethnic, or cultural } \\
\text { diversity in engineering }\end{array}$ & 3.933 & 0.848 & -0.677 & 0.489 \\
\hline CE3: Sustainable issues in engineering practice & 4.124 & 0.717 & -0.693 & 1.016 \\
\hline $\begin{array}{l}\text { CE4: Understanding how engineering solutions can be } \\
\text { shaped by environmental, cultural, economic, and } \\
\text { other considerations }\end{array}$ & 4.080 & 0.750 & -0.716 & 1.015 \\
\hline
\end{tabular}


Table 2. Cont.

\begin{tabular}{|c|c|c|c|c|}
\hline Variables/Measurement Items & Mean & SD & Skewness & Kurtosis \\
\hline \multicolumn{5}{|l|}{ Instructional practice (IP) } \\
\hline $\begin{array}{l}\text { IP1: Used examples, cases, or metaphors to explain } \\
\text { sustainability-related concepts }\end{array}$ & 3.929 & 0.807 & -0.643 & 0.569 \\
\hline $\begin{array}{l}\text { IP2: Introduced how sustainability is connected } \\
\text { to engineering }\end{array}$ & 3.951 & 0.793 & -0.621 & 0.583 \\
\hline $\begin{array}{l}\text { IP3: Explained sustainability-related concepts by } \\
\text { linking them to what students already know }\end{array}$ & 3.920 & 0.825 & -0.653 & 0.526 \\
\hline $\begin{array}{l}\text { IP4: Provided support if and when students felt } \\
\text { challenged by the sustainability content }\end{array}$ & 3.915 & 0.836 & -0.716 & 0.601 \\
\hline \multicolumn{5}{|l|}{ Sustainable agency belief (SAB) } \\
\hline $\begin{array}{l}\text { SAB1: Engineering will provide greater opportunities } \\
\text { for future generations }\end{array}$ & 3.945 & 0.819 & -0.424 & -0.061 \\
\hline $\begin{array}{l}\text { SAB2: A country needs engineering to } \\
\text { become developed }\end{array}$ & 4.003 & 0.853 & -0.860 & 1.124 \\
\hline $\begin{array}{l}\text { SAB3: Engineering make our lives healthier, easier, } \\
\text { and more comfortable }\end{array}$ & 3.984 & 0.867 & -0.862 & 1.059 \\
\hline $\begin{array}{l}\text { SAB4: The benefits of new engineering technologies } \\
\text { for sustainable development greatly outweigh the risks }\end{array}$ & 4.080 & 0.816 & -0.910 & 1.385 \\
\hline \multicolumn{5}{|l|}{ Sustainable knowledge (SK) } \\
\hline $\begin{array}{c}\text { SK1: Respecting human rights is necessary for } \\
\text { sustainable development }\end{array}$ & 4.442 & 0.797 & -1.784 & 3.913 \\
\hline $\begin{array}{l}\text { SK2: To achieve sustainable development, all the } \\
\text { people in the world must have access to } \\
\text { good education }\end{array}$ & 4.106 & 0.972 & -1.001 & 0.449 \\
\hline $\begin{array}{l}\text { SK3: Sustainable development requires a fair } \\
\text { distribution of goods and services among people in } \\
\text { the world }\end{array}$ & 4.029 & 1.016 & -0.924 & 0.226 \\
\hline $\begin{array}{c}\text { SK4: Wiping out poverty in the world is necessary for } \\
\text { sustainable development }\end{array}$ & 4.195 & 0.888 & -1.099 & 1.028 \\
\hline $\begin{array}{l}\text { SK5: Sustainable development requires a shift to } \\
\text { renewable natural resources }\end{array}$ & 4.427 & 0.691 & -1.512 & 4.154 \\
\hline \multicolumn{5}{|l|}{ Sustainable attitude (SA) } \\
\hline $\begin{array}{l}\text { SA1: I think that everyone ought to be given the } \\
\text { opportunity to acquire the knowledge, values, and } \\
\text { skills that are necessary to live sustainably }\end{array}$ & 4.481 & 0.690 & -1.726 & 4.822 \\
\hline $\begin{array}{l}\text { SA2: I think that companies have a responsibility to } \\
\text { reduce the use of packaging and disposable articles }\end{array}$ & 4.528 & 0.658 & -1.903 & 6.319 \\
\hline $\begin{array}{l}\text { SA3: I think that we who are living now should make } \\
\text { sure that people in the future enjoy the same quality of } \\
\text { life as we do today }\end{array}$ & 4.460 & 0.717 & -1.745 & 4.706 \\
\hline $\begin{array}{l}\text { SA4: I think that people who pollute land, air, or water } \\
\text { should pay for the damage they cause to } \\
\text { the environment }\end{array}$ & 4.480 & 0.675 & -1.626 & 4.595 \\
\hline $\begin{array}{l}\text { SA5: I think that it is important to take measures } \\
\text { against problems which have to do with } \\
\text { climate change }\end{array}$ & 4.503 & 0.656 & -1.724 & 5.442 \\
\hline
\end{tabular}


Table 2. Cont.

\begin{tabular}{|c|c|c|c|c|}
\hline Variables/Measurement Items & Mean & SD & Skewness & Kurtosis \\
\hline \multicolumn{5}{|l|}{ Sustainable behavior (SB) } \\
\hline $\begin{array}{c}\text { SB1: Where possible, I choose to cycle or walk when } \\
\text { I'm going somewhere, instead of travelling by } \\
\text { motor vehicle }\end{array}$ & 4.426 & 0.719 & -1.459 & 3.228 \\
\hline $\begin{array}{l}\text { SB2: When I use a computer or mobile to chat, to text, } \\
\text { to play games, and so on, I always treat others as } \\
\text { respectfully as I would in real life }\end{array}$ & 4.404 & 0.746 & -1.614 & 3.921 \\
\hline SB3: I do things that help poor people & 4.225 & 0.771 & -0.947 & 1.376 \\
\hline $\begin{array}{l}\text { SB4: I avoid buying goods from companies with a bad } \\
\text { reputation for looking after their employees and } \\
\text { the environment }\end{array}$ & 4.274 & 0.769 & -1.129 & 1.923 \\
\hline $\begin{array}{l}\text { SB5: I have changed my personal lifestyle in order to } \\
\text { reduce waste }\end{array}$ & 4.396 & 0.678 & -1.280 & 3.207 \\
\hline
\end{tabular}

\subsection{Data Analysis}

In this study, structural equation modeling (SEM) analysis with the maximum-likelihood estimation method was conducted to examine the hypothesized relationships among curricular emphasis, instructional practice, sustainable agency beliefs, and sustainability consciousness. Our analysis followed the two-step strategy outlined by Anderson and Gerbing [73], namely, the measurement model and structural model analyses. The indices that evaluated the model's goodness of fit were the ratio of chi-square to the degree of freedom $\left(\chi^{2} / \mathrm{df}\right)$, goodness-of-fit index (GFI), adjusted goodness-of-fit index (AGFI), comparative fix index (CFI), incremental fit index (IFI), Tucker-Lewis index (TLI), standardized root mean square residual (SRMR), and root mean square error of approximation (RMSEA). For a good fit, $\chi^{2} / \mathrm{df}$ should be lower than 5; GFI, AGFI, CFI, IFI, and TLI should be greater than 0.90; and SRMR and RMSEA should be lower than 0.08 [74]. To examine the mediating role of sustainable agency beliefs, we used the bootstrapping procedure (2000 bootstrap samples) to calculate the indirect effects of curriculum experience on sustainability consciousness (via sustainable agency beliefs) and their associated $95 \%$ confidence intervals (CI). Significance of an indirect effect was determined if the 95\% bias-corrected bootstrap CI that does not include zero. The bootstrapping approach shows better statistical property than the Sobel test or causal steps method while decreasing the probability of Type 1 error [75]. Furthermore, multigroup SEM analysis was used to test the moderating effect of gender because it is a more commonly preferred and powerful technique to detect structural invariance [76]. All the above analyses were performed in Amos 23 software package.

\section{Results}

\subsection{Measurement Model}

Confirmatory factor analysis (CFA) was conducted to assess the fitness of the measurement model to the research data before structural model analysis. The measurement model consisted of six latent variables and 27 observed indicators. In the CFA, we permitted all latent variables to correlate with one another, and observed indicators were constrained to load only on their respective latent constructs. Figure 2 demonstrates the results of the CFA. The results suggested that the measurement model had a satisfactory fit to the survey data $\left(\chi^{2}=1107.154 ; \mathrm{df}=309 ; \chi^{2} / \mathrm{df}=3.583 ; \mathrm{GFI}=0.955 ;\right.$ AGFI $=0.945$; $\mathrm{CFI}=0.975 ; \mathrm{IFI}=0.975 ; \mathrm{TLI}=0.971$; SRMR $=0.035 ; \mathrm{RMSEA}=0.038$ [90\% CI: 0.035, 0.040]). The standardized factor loadings of all indicators were significant and greater than the threshold of 0.50 (from 0.656 to 0.955 ) [74]. 


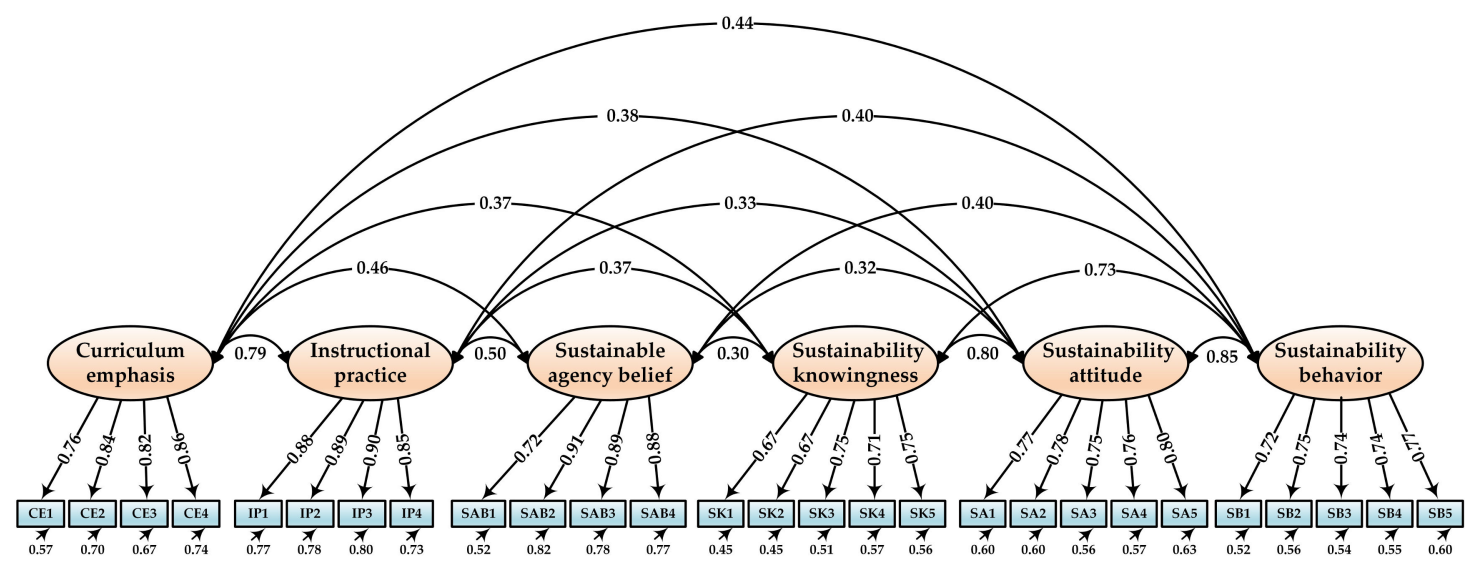

Figure 2. Results of confirmatory factor analysis (CFA).

In addition, Harman's one-factor test were applied to determine the common method variance in the data [77]. In doing so, we compared the fit of one-factor (common method) model with the six-factor measurement model. The results showed that the single-factor model (all items were constrained to load together on one latent construct) had a poor data fit $\left(\chi^{2}=15314.926 ; \mathrm{df}=324 ; \chi^{2} / \mathrm{df}=47.268\right.$; $\mathrm{GFI}=0.428 ; \mathrm{AGFI}=0.332 ; \mathrm{CFI}=0.528 ; \mathrm{IFI}=0.528 ; \mathrm{TLI}=0.488 ; \mathrm{SRMR}=0.142 ; \mathrm{RMSEA}=0.160[90 \%$ CI: $0.158,0.162]$. The chi-square statistic $\left(\Delta \chi^{2}=14207.772, \Delta \mathrm{df}=15, \mathrm{p}<0.001\right)$ supported that the six-factor model yielded a remarkably better fit to the data than the one-factor model, indicating that common method variance was absent in this study.

After the CFA analysis, we calculated the Cronbach's $\alpha$ coefficients and composite reliability values to assess the reliability of the measures. As shown in Table 3, Cronbach's $\alpha$ coefficients of the scales ranged from 0.832 to 0.930 , higher than the standard value of 0.700 [78]. The values for composite reliability (CR) ranged from 0.837 to 0.930 and were greater than the threshold level of 0.700 [79]. Additionally, the average variance extracted (AVE) scores ranged from 0.507 to 0.770 and were greater than the recommended value of 0.50 . These results suggested satisfactory internal consistency reliability, composite reliability, and convergent validity of the measures in this study [80].

Table 3. The standard factor loading and reliability.

\begin{tabular}{|c|c|c|c|c|c|}
\hline Variables & Items & Loading & Cronbach's $\alpha$ & CR & AVE \\
\hline \multirow{4}{*}{ Curricular emphasis (CE) } & CE1 & 0.755 & \multirow{4}{*}{0.887} & \multirow{4}{*}{0.890} & \multirow{4}{*}{0.668} \\
\hline & CE2 & 0.835 & & & \\
\hline & CE3 & 0.816 & & & \\
\hline & CE4 & 0.861 & & & \\
\hline \multirow{4}{*}{ Instructional practice (IP) } & IP1 & 0.875 & \multirow{4}{*}{0.930} & \multirow{4}{*}{0.930} & \multirow{4}{*}{0.770} \\
\hline & IP2 & 0.885 & & & \\
\hline & IP3 & 0.896 & & & \\
\hline & IP4 & 0.853 & & & \\
\hline \multirow{4}{*}{ Sustainable agency belief (SAB) } & SAB1 & 0.719 & \multirow{4}{*}{0.908} & \multirow{4}{*}{0.911} & \multirow{4}{*}{0.722} \\
\hline & SAB2 & 0.906 & & & \\
\hline & SAB3 & 0.885 & & & \\
\hline & SAB4 & 0.875 & & & \\
\hline \multirow{5}{*}{ Sustainability knowingness (SK) } & SK1 & 0.672 & \multirow{5}{*}{0.832} & \multirow{5}{*}{0.837} & \multirow{5}{*}{0.507} \\
\hline & SK2 & 0.671 & & & \\
\hline & SK3 & 0.748 & & & \\
\hline & SK4 & 0.712 & & & \\
\hline & SK5 & 0.754 & & & \\
\hline
\end{tabular}


Table 3. Cont.

\begin{tabular}{cccccc}
\hline Variables & Items & Loading & Cronbach's $\alpha$ & CR & AVE \\
\hline \multirow{2}{*}{ Sustainability attitude (SA) } & SA1 & 0.774 & & & \\
& SA2 & 0.775 & & & \\
& SA3 & 0.745 & 0.878 & 0.879 & \\
& SA4 & 0.756 & & & \\
& SA5 & 0.796 & & & \\
Sustainability behavior (SB) & SB1 & 0.722 & & \\
& SB2 & 0.749 & & & \\
& SB3 & 0.735 & 0.860 & & \\
\hline
\end{tabular}

$\mathrm{CR}=$ composite reliability; AVE = average variance extracted.

Table 4 presents the correlation coefficients of all measures and the square roots of the AVEs. As demonstrated in this table, correlations between variables ranged from 0.274 to 0.877 ( $p<0.001$ ). Furthermore, the square roots of the AVEs for each measure were higher than their associated pair of correlations, providing evidence for the discriminant validity of the measures in this study [80].

Table 4. Correlation and discriminant validity.

\begin{tabular}{|c|c|c|c|c|c|c|}
\hline Variables & 1 & 2 & 3 & 4 & 5 & 6 \\
\hline 1. Curricular emphasis & 0.817 & & & & & \\
\hline 2. Instructional practice & $0.725^{* * *}$ & 0.877 & & & & \\
\hline 3. Sustainable agency belief & $0.445^{* * *}$ & $0.483^{* * *}$ & 0.850 & & & \\
\hline 4. Sustainability knowingness & $0.322 * * *$ & $0.325^{* * *}$ & $0.274^{* * *}$ & 0.712 & & \\
\hline 5. Sustainability attitude & $0.336^{* * *}$ & $0.299 * * *$ & $0.299 * * *$ & $0.669^{* * *}$ & 0.768 & \\
\hline 6. Sustainability behavior & $0.389 * * *$ & $0.362 * * *$ & $0.374^{* * *}$ & $0.612 * * *$ & $0.743^{* * *}$ & 0.744 \\
\hline
\end{tabular}

\subsection{Structural Model}

SEM analysis was performed to test the hypothesized relationships among variables. The SEM results indicated that the structural model exhibited adequate fit $\left(\chi^{2}=1107.154 ; \mathrm{df}=309 ; \chi^{2} / \mathrm{df}=3.583\right.$; $\mathrm{GFI}=0.955 ; \mathrm{AGFI}=0.945 ; \mathrm{CFI}=0.975 ; \mathrm{IFI}=0.975 ; \mathrm{TLI}=0.971 ; \mathrm{SRMR}=0.035 ; \mathrm{RMSEA}=0.038$ [90\% CI: 0.035, 0.040]). The statistical significance of the direct paths among variables was examined. First, both curricular emphasis $(\beta=0.185, \mathrm{t}=4.363, p<0.001)$ and instructional practice $(\beta=0.349$, $\mathrm{t}=8.308, p<0.001$ ) had significant impacts on sustainable agency beliefs. Second, curricular emphasis exerted significant impacts on all of the dimensions of sustainability consciousness (i.e., sustainability knowingness: $\beta=0.200, \mathrm{t}=4.201, p<0.001$; sustainability attitude: $\beta=0.274, \mathrm{t}=5.872, p<0.001$; sustainability behavior: $\beta=0.288, \mathrm{t}=6.301, p<0.001$ ). Third, the direct influence of instructional practice on sustainability knowingness was significant $(\beta=0.140, \mathrm{t}=2.947, p<0.01)$, while the direct effects of instructional practice on both sustainability attitude $(\beta=0.023, \mathrm{t}=0.491, p>0.05)$ and sustainability behavior $(\beta=0.054, \mathrm{t}=1.205, p>0.05)$ were not significant. Lastly, sustainable agency beliefs had significant effects on sustainability knowingness $(\beta=0.136, \mathrm{t}=4.575, p<0.001)$, sustainability attitude $(\beta=0.180, \mathrm{t}=6.223, p<0.001)$, and sustainability behavior $(\beta=0.242, \mathrm{t}=8.447$, $p<0.001)$. Figure 3 shows the SEM results.

We further conducted a bootstrapping analysis to strictly examine the mediation role of sustainable agency beliefs. As shown in Table 5, both the direct and indirect effect sizes of curricular emphasis on the three dimensions of sustainability consciousness were significant. Similarly, the direct and indirect effect sizes of instructional practice on sustainability knowingness were significant, indicating 
that sustainable agency beliefs exerted a partial mediating effect on these relationships. However, the direct effect size of instructional practice on sustainability attitude and sustainability behavior was not significant, indicating that sustainable agency beliefs fully mediated these two relationships. Thus, $\mathrm{H} 1 \mathrm{a}, \mathrm{H} 2 \mathrm{a}$, and $\mathrm{H} 2 \mathrm{~b}$ are supported, whereas $\mathrm{H} 1 \mathrm{~b}$ is only partially supported.

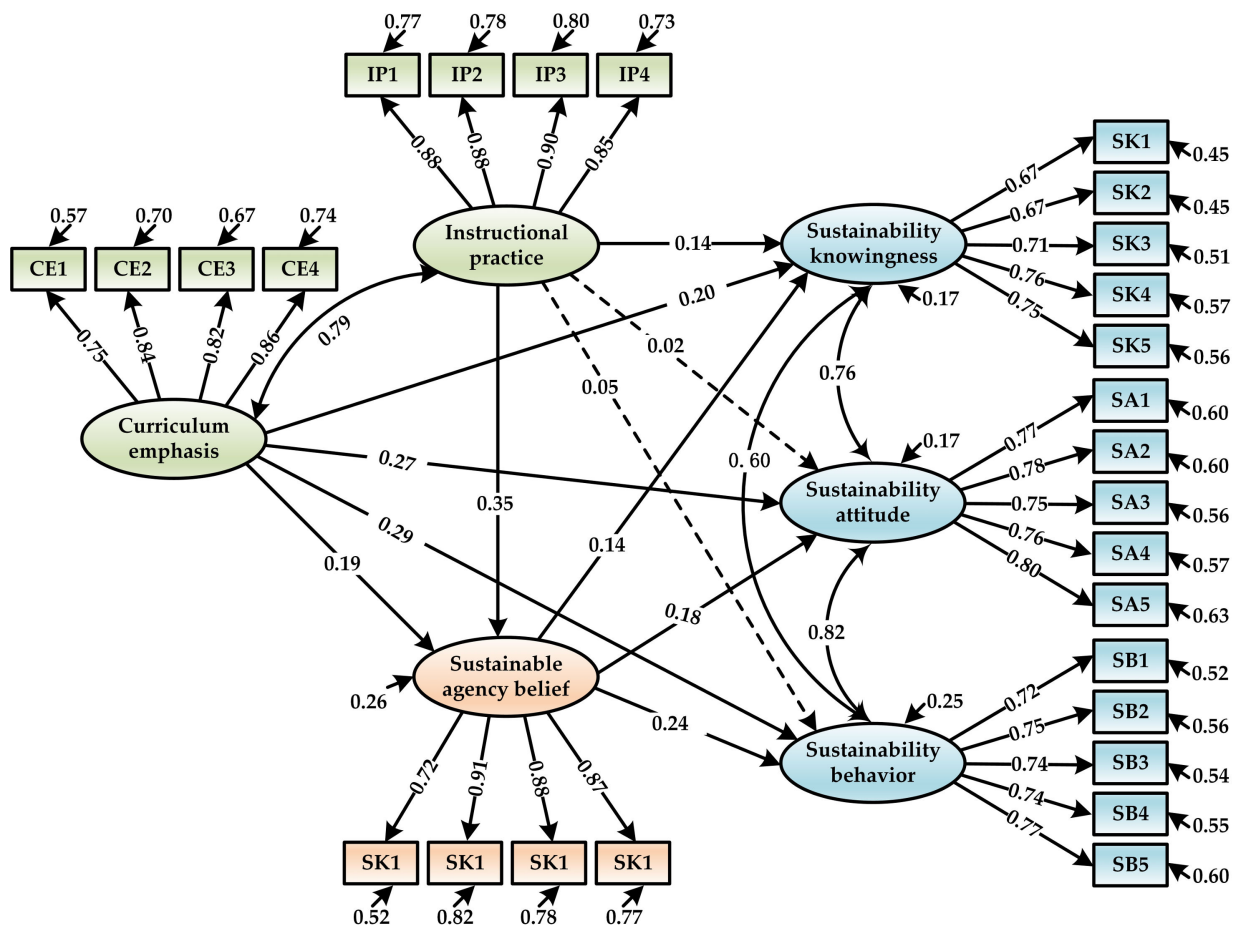

Figure 3. The results of structural equation modeling (SEM).

Table 5. The results of bootstrapping analysis.

\begin{tabular}{cccccc}
\hline \multirow{2}{*}{ Paths } & \multicolumn{2}{c}{ Bootstrapping } & \multicolumn{2}{c}{ 95\% Bias-Corrected CI } & \multirow{2}{*}{$\boldsymbol{p}$} \\
\cline { 2 - 4 } & Effect & Boot S. E. & Boot LLCI & Boot ULCI & \\
\hline $\mathrm{CE} \rightarrow \mathrm{SK}$ & 0.200 & 0.055 & 0.097 & 0.311 & 0.001 \\
$\mathrm{CE} \rightarrow \mathrm{SA}$ & 0.274 & 0.054 & 0.169 & 0.380 & 0.001 \\
$\mathrm{CE} \rightarrow \mathrm{SB}$ & 0.288 & 0.052 & 0.185 & 0.390 & 0.001 \\
$\mathrm{CE} \rightarrow \mathrm{SAB}$ & 0.185 & 0.057 & 0.071 & 0.297 & 0.003 \\
$\mathrm{IP} \rightarrow \mathrm{SK}$ & 0.140 & 0.050 & 0.039 & 0.233 & 0.012 \\
$\mathrm{IP} \rightarrow \mathrm{SA}$ & 0.023 & 0.043 & -0.070 & 0.104 & 0.661 \\
$\mathrm{IP} \rightarrow \mathrm{SB}$ & 0.054 & 0.047 & -0.038 & 0.148 & 0.244 \\
$\mathrm{IP} \rightarrow \mathrm{SAB}$ & 0.349 & 0.053 & 0.246 & 0.452 & 0.001 \\
$\mathrm{SAB} \rightarrow \mathrm{SK}$ & 0.136 & 0.033 & 0.074 & 0.202 & 0.001 \\
$\mathrm{SAB} \rightarrow \mathrm{SA}$ & 0.180 & 0.036 & 0.112 & 0.255 & 0.001 \\
$\mathrm{SAB} \rightarrow \mathrm{SB}$ & 0.242 & 0.034 & 0.174 & 0.308 & 0.001 \\
$\mathrm{CE} \rightarrow \mathrm{SAB} \rightarrow \mathrm{SK}$ & 0.025 & 0.010 & 0.009 & 0.050 & 0.002 \\
$\mathrm{CE} \rightarrow \mathrm{SAB} \rightarrow \mathrm{SA}$ & 0.033 & 0.012 & 0.012 & 0.063 & 0.002 \\
$\mathrm{CE} \rightarrow \mathrm{SAB} \rightarrow \mathrm{SB}$ & 0.045 & 0.016 & 0.018 & 0.080 & 0.002 \\
$\mathrm{IP} \rightarrow \mathrm{SAB} \rightarrow \mathrm{SK}$ & 0.048 & 0.013 & 0.025 & 0.078 & 0.000 \\
$\mathrm{IP} \rightarrow \mathrm{SAB} \rightarrow \mathrm{SA}$ & 0.063 & 0.016 & 0.036 & 0.100 & 0.001 \\
$\mathrm{IP} \rightarrow \mathrm{SAB} \rightarrow \mathrm{SB}$ & 0.085 & 0.017 & 0.056 & 0.124 & 0.001 \\
\hline
\end{tabular}

$\mathrm{CE}$ = curricular emphasis; IP = instructional practice; $\mathrm{SAB}$ = sustainable agency belief; $\mathrm{SK}$ = sustainability knowingness; $\mathrm{SA}=$ sustainability attitude; $\mathrm{SB}$ = sustainability behavior. 


\subsection{Moderating Effects}

We conducted Multigroup SEM analyses to determine the moderating role of gender in the research model. The sample was classified into female and male student subgroups using the dichotomous variable of gender. Chi-square test was utilized to compare a constrained model (i.e., all path coefficients were specified to be equal across the two groups) with an unconstrained model (i.e., all path coefficients were allowed to vary across the two groups). If the constrained model exerts a greater chi-square coefficient than the constrained model, the moderating effect is supported [79]. In each model, factor loadings between the two groups were kept constant to assure that the variables were being measured equally across groups; however, error variances were permitted to vary across groups [81]. The chi-square statistic demonstrated a significant difference $\left(\Delta \chi^{2}=20.406, \mathrm{df}=11, p<\right.$ $0.05)$ between the constrained $\left(\chi^{2}=1715.090, \mathrm{df}=655\right)$ and unconstrained model $\left(\chi^{2}=1694.684, \mathrm{df}=\right.$ $644)$, supporting a potential moderation effect of gender.

To discern the moderator effects on each relationship, a sequence of chi-square difference tests were performed by comparing the constrained models with 11 different models respectively, each permitting only one of the hypothesized structural relationships to be unconstrained. The results illustrate that only four out of the 11 paths were significantly moderated by gender (see Table 6). Specifically, the effect of curricular emphasis on sustainable agency beliefs was stronger for male students $(\beta=0.224, p<0.001)$ than for female students $(\beta=0.129, p<0.05)$. Similarly, the influence of instructional practice on sustainable agency beliefs was stronger for male students $(\beta=0.390, p<0.001)$ than for female students $(\beta=0.273, p<0.001)$. On the other hand, female students $(\beta=0.213, p<0.001)$ exhibited greater path coefficients than male students $(\beta=0.140, p<0.001)$ in the impact of instructional practice on sustainability knowingness, and the effect of sustainable agency beliefs on sustainability knowingness was also weaker for male students $(\beta=0.102, p<0.01)$ than for female students $(\beta=0.216$, $p<0.001)$. Hence, $\mathrm{H} 3$ is partially supported.

Table 6. Results of the multigroup SEM analysis.

\begin{tabular}{ccccc}
\hline & \multicolumn{2}{c}{ Standardized Coefficients } & \multirow{2}{*}{$\chi^{2}(d f)$} & \multirow{2}{*}{$\Delta \chi^{2}(\Delta d f)$} \\
\cline { 2 - 3 } & Female & Male & & \\
\hline Constrained model & - & - & $1715.090(655)$ & - \\
$\mathrm{CE} \rightarrow \mathrm{SAB}$ & $0.129^{*}$ & $0.224^{* * *}$ & $1708.895(654)$ & $6.195^{*}$ \\
$\mathrm{IP} \rightarrow \mathrm{SAB}$ & $0.273^{* * *}$ & $0.390^{* * *}$ & $1708.174(654)$ & $6.915^{* *}$ \\
$\mathrm{IP} \rightarrow \mathrm{SK}$ & $0.213^{* * *}$ & $0.140^{* * *}$ & $1710.936(654)$ & $4.153^{*}$ \\
$\mathrm{SAB} \rightarrow \mathrm{SK}$ & $0.216^{* * *}$ & $0.102^{* *}$ & $1705.656(654)$ & $9.433^{* *}$ \\
\hline
\end{tabular}

\section{Discussion}

The purpose of this study was to examine the influencing factors of sustainability consciousness among engineering undergraduates in China. With a modified college impact model, we examined the hypothesized links among curriculum experiences, sustainable agency beliefs, and three dimensions of sustainability consciousness, and tested the moderating role of gender on the relationships among research variables. The results of a series of analyses provided support for most relations proposed in the hypothesized model, and the main results are discussed below. Our study is a response to scholars' call for more empirical research on how sustainability education (e.g., curriculum experiences) impacts the sustainability-related learning outcomes of undergraduates in the context of engineering education [82].

In line with the college impact model, the current study emphasized the direct impact of curriculum experience on the sustainability consciousness of engineering undergraduates. Our study revealed that curricular emphasis has a significant, positive influence on all three dimensions of engineering students' sustainability consciousness. These findings are supported by previous studies that demonstrated that 
the embedding of sustainability and sustainable development issues into formal courses benefits the formation of engineering students' sustainability consciousness [47]. A possible explanation for this might be that the values and beliefs of engineering undergraduates are in a transitional state; thus, the knowledge, skills, and information delivered in formal courses, such as sustainable thinking and the influences of different dimensions of sustainable development on engineering, foster a positive change in their values and beliefs toward sustainability [83], which play a fundamental role in guiding sustainability knowingness, attitudes, and behaviors according to the value-belief-norm theory [84].

Consistent with previous studies [85], student-centered instructional practice was found to significantly and positively influence sustainability knowingness. Contrary to expectations, however, instructional practice has no significant direct effect on sustainability attitude and behavior in this study. These findings may be explained by a consensus in the environmental education literature that teaching sustainable issues would increase their sustainability knowledge level, whereas the development of sustainability attitudes and behaviors is a more complex process that is determined by the interactions among various individual and environmental factors, and unlikely to be automatically achieved as a result of instruction [29]. Student-centered approaches have been generally regarded as a feasible means of tackling the challenges of sustainability education [86]. However, the effectiveness of such instructional practice can be largely dependent on the positive attitude and sufficient knowledge of engineering faculty toward teaching sustainability [87]. In fact, it was not until China became the formal member of Washington Accord in 2016 that a large number of engineering programs needing accreditation began to integrate sustainability into their curricula. The idea and implementation of sustainable education are rather new to some engineering faculty and instructors. Thus, instructors in the current study delivered sustainability knowledge by using certain pedagogies, and they may be inexperienced and reluctant to further facilitate students' active and meaningful learning about sustainability due to the lack of necessary resources and support.

The results indicate that both curricular emphasis and instructional practice are significantly related to sustainable agency beliefs, which in turn have a positive impact on three dimensions of sustainability consciousness. The mediating effects of engineering students' sustainable agency beliefs in the relationship between the two aspects of curriculum experiences and sustainability consciousness dimensions were supported through a bootstrapping test. Specifically, sustainable agency beliefs partially mediate the relationship between instructional practice and sustainability knowingness while fully mediating instructional practices and sustainability attitudes and behavior linkages; the effects of curricular emphasis and three dimensions of sustainability consciousness are partially mediated by sustainable agency beliefs. These results indicate that sustainable agency beliefs play a critical role in bridging sustainability education and students' sustainability learning outcomes. In line with the perspective of Tang [47], with increasing emphasis on sustainability and appropriate instructional methods in the curriculum, engineering students may be expected to contribute to sustainable engineering practice, which requires them to have not only knowledge of sustainable development, but also an agency belief toward sustainable development. That is, the accessibility of external curricular and instructional support, resources, and information for sustainability might lead to the enhancement of knowingness, attitude, and behavior toward sustainability by shaping a positive environment needed for engineering undergraduates' sustainable agency beliefs to flourish.

We found that both influences of curricular emphasis and instructional practice on sustainable agency beliefs are significantly stronger among male undergraduates than among female undergraduates. These findings indicate that the sustainable knowledge, skills, and information taught by student-centered courses are critical for male students to develop sustainable agency beliefs. However, for female students, curricular emphasis and instructional practice appear to play a limited role in sustainability agency belief construction. A possible explanation might be that curriculum experiences during college may not be as important for females' agency beliefs toward sustainability as they are for males because "women who decide to enter the field of STEM show a very strong expectation that they can make the world a better place" [88] (p. 168). These 
results reveal that instructional practice and sustainable agency beliefs have stronger effects on female students' sustainability knowingness than on that of male students. Consistent with the findings of Olsson and Gericke [17], the results in the present study imply that female students rely more on instructional practice, such as a student-centered approach characterized by interactional participation and intellectual stimulation, to acquire knowledge of the fundamentals of sustainable development. Instead, male students may develop their sustainability knowledge from different sources because of the male advantage in the engineering field.

\section{Implications}

The current study provides several theoretical implications. First, our study broadens the research on engineering undergraduates' sustainability learning outcomes from a college experiences view with a modified college impact model. Although formal curriculum is known to be a critical educational factor for fostering students' sustainability consciousness, quantitative evidence on the association between curriculum experiences and engineering undergraduates' sustainability consciousness is limited. This study investigates the direct impacts of two aspects of curriculum experiences, namely, curricular emphasis and instructional practice, on the sustainability consciousness of engineering undergraduates in China to bridge this void. The findings of this study demonstrate that the effects of curricular emphasis and instructional practice vary in predicting three dimensions of students' sustainability consciousness. That is, curricular emphasis can significantly influence all three dimensions of students' sustainability consciousness, while instructional practice had a significant effect only on the sustainability knowingness dimension of sustainability consciousness. The findings of this study contribute to our understanding regarding student sustainability-related curriculum experiences in the context of engineering professional accreditation and promoting sustainable engineering education in China.

Second, to the best of our knowledge, this is the first report to offer empirical evidence on the substantial role of sustainable agency beliefs in linking the association between curriculum variables and undergraduates' sustainability learning outcomes within the context of engineering education. College impact theorists acknowledge that students may bring different quantities and forms of psychological energy into their learning process, and therefore have different levels of participation [35]. However, agency beliefs are not explicitly considered in the college impact model as an explanatory factor of learning outcomes. the majority of previous studies have dealt only with the direct relations between the implementation of sustainable engineering education and engineering students' learning outcomes toward sustainability, neglecting the psychological and motivational mechanism between them. Therefore, by incorporating sustainable agency beliefs in the college impact model, this study provides evidence of the bridging role of sustainable agency beliefs in connecting curriculum experiences and engineering undergraduates' sustainability consciousness in the Chinese context.

Third, this study includes gender as a moderator into the college impact model, thus offering a more holistic view of the impacting mechanism of curriculum experiences and sustainable agency beliefs on sustainability consciousness within the engineering education context, and responding to the call for further investigation of the gender gap in the relationships among sustainability consciousness and its determinants, not only limited to testing the gender difference in sustainability consciousness itself [17]. Furthermore, according to Ro and Knight [16], the male-dominated population in the engineering context "washes out" the evidence that is unique to women. Therefore, testing the moderating effects of gender may be helpful for identifying critical relationships that are present for the female student population.

Additionally, the current study develops the effectiveness of the modified college impact model as a sound theoretical lens for understanding engineering undergraduates' development. This research extends the applying scope of the college impact model to the research field of awareness skills development, thereby responding to the call for the college impact model to be used not only for explaining engineering students' process skills, such as communication skills and teamwork skills, 
but also for sustainability consciousness, as it is deemed a critical awareness skill for preparing engineering undergraduates to better comprehend the influence of engineering solutions in a global, economic, environmental, and societal context [89]. Moreover, college impact model is also a possibly beneficial basic framework for future studies into engineering students' overall learning outcomes under a diversified engineering education environment around the world due to its scalability and versatility supported in the current study and previous studies.

The results of this study also highlight some important practical implications that may beneficial for promoting the integration of sustainability into engineering education. First, the findings reveal that instructional practice fails to significantly impact engineering undergraduates' sustainability attitudes and sustainability behaviors. This is not to say that instructional practice is unnecessary; in fact, instructional practice can yield a crucial indirect effect on sustainability consciousness via students' agency beliefs about engineering to improve the sustainable development of the world. Teaching and learning sustainability is essentially a student-centered process [61]. Perhaps universities and engineering programs should construct a more efficient mechanism to invest in the instructional process and further train teachers to master student-centered approaches toward facilitating and guiding students' active and meaningful learning. Second, policymakers and practitioners of engineering education should pay more attention to engineering undergraduates' agency belief enhancement, which will assist undergraduates to determine which actions and goals to pursue. Agency beliefs can be seen as a positive psychological construct that is open to management, intervention, and change [90]. Thus, this study recommends that the engineering programs build platforms to offer sustainable agency belief training to undergraduates to enable them to improve knowledge, attitudes, and behaviors toward sustainable engineering. Third, on the basis of current and previous findings, certain curricular and instructional operations that might implement more effectively for females or males are suggested. We speculate that interventions that emphasize more sustainability-related skills and values in courses and student-centered teaching approaches are especially helpful for enhancing male students' beliefs toward the capacity of engineering to bring beneficial outcomes to the world, whereas female students' sustainability knowingness may benefit more from the interventions of the student-centered teaching method.

\section{Limitations and Future Study}

There are several limitations should be taken into consideration in future research. First, given that curriculum experiences, sustainable agency beliefs, and sustainability consciousness may change over a four-year period of time, a self-reported survey and cross-sectional design are used in this study may limit the accurate and complete reflection of the contribution of engineering education on undergraduates' sustainability consciousness development. Therefore, a longitudinal study design may be a beneficial way to assess the causal associations among factors in college impact models and engineering undergraduates' literacy development.

Second, the respondents of our study consisted of engineering undergraduates from the accredited engineering programs of five traditional engineering disciplines in developed areas in China. China is one of the formal members of the Washington Accord, which means the substantial equivalence of approaches and systems for accrediting engineering programs between China and other members. In this sense, the results of our study are comparable to other similar studies conducted on accrediting engineering programs in other countries or areas. However, the current study is limited by its generalizability to other non-accredited engineering programs or other engineering disciplines. Therefore, future studies should be conducted to engineering with students from a broader scope of engineering education programs, thus enhancing the generalizability and validity of research findings or revising the framework utilized to understand the influential mechanism of environmental and individual factors on engineering students' sustainability consciousness.

Third, in this research, we examined only the role of curricular factors in shaping students' consciousness, and future research needs to further test the effect of out-of-class experiences, which 
are also critical avenues for students to learn about sustainability issues. Moreover, we suggest that other critical mediation and moderation mechanisms via which college experiences can influence engineering students' sustainability learning outcomes should be taken into account in future research due to the complexity and transformation of engineering education around the world, thus producing valuable and creative theoretical and practical outcomes and promoting research into increasing the diversity of engineering education.

Author Contributions: Conceptualization, X.L. and Q.Z.; methodology, X.L.; formal analysis, X.L. and Q.Z.; investigation, M.Y. and D.W.; writing — original draft preparation, X.L.; writing-review and editing, Q.Z.; supervision, Y.M. and X.Z.; funding acquisition, X.L. and Y.M.; All authors have read and agreed to the published version of the manuscript.

Funding: This research was funded by Beijing Social Science Fund Research Base Project (No. 18JDJYB007), Project of Social Science Plan of Beijing Municipal Education Commission (No. SM201910005004), Education and Teaching Project of Beijing University of Technology (No. ER2018C020201), Program for Rixin Talents of Beijing University of Technology (No. 103000514118003), and Special Funds of the Generalized Virtual Economy Research (No. GX2010-1014 [Y]).

Acknowledgments: We would like to thank the undergraduates for participating in the survey and the student activities advisors for their assistance in data collection.

Conflicts of Interest: The authors declare no conflict of interest.

\section{References}

1. Chinese Engineering Education Accreditation Association. Criteria for Engineering Education Accreditation. 2017. Available online: http:/www.ceeaa.org.cn/jyzyrzxh/resource/cms/article/599823/617698/2020021318484 778597.docx (accessed on 20 February 2020).

2. Accreditation Board for Engineering and Technology. Criteria for Accrediting Engineering Programs, 2020-2021. 2019. Available online: https://www.abet.org/accreditation/accreditation-criteria/criteria-for-acc rediting-engineering-programs-2020-2021/\#GC3 (accessed on 15 March 2020).

3. Engineering Council. The UK Standard for Professional Engineering Competence (UK-SPEC). 2014. Available online: http://www.engineeringgateways.co.uk/professional-qualifications/standards/uk-spec.aspx (accessed on 15 March 2020).

4. Engineers Canada. Accreditation Criteria and Procedures Report. 2019. Available online: https://engineersc anada.ca/accreditation/accreditation-resources (accessed on 15 March 2020).

5. Engineers Australia. Competency Standard for Professional Engineer. 2019. Available online: https: //www.engineersaustralia.org.au/sites/default/files/2019-11/Stage1_Competency_Standards.pdf (accessed on 15 March 2020).

6. Japan Accreditation Board for Engineering Education. Common Criteria for Accreditation of Professional Education Programs. 2019. Available online: https://jabee.org/en/accreditation/basis (accessed on 15 March 2020).

7. Mulder, K.; Segalàs-Coral, J.; Ferrer-Balas, D. Educating engineers for/in sustainable development? What we knew, what we learned, and what we should learn. Therm. Sci. 2010, 14, 625-639. [CrossRef]

8. Thürer, M.; Tomašević, I.; Stevenson, M.; Qu, T.; Huisingh, D. A systematic review of the literature on integrating sustainability into engineering curricula. J. Clean. Prod. 2018, 181, 608-617. [CrossRef]

9. Michalos, A.C.; Creech, H.; Swayze, N.; Maurine Kahlke, P.; Buckler, C.; Rempel, K. Measuring Knowledge, Attitudes and Behaviours Concerning Sustainable Development among Tenth Grade Students in Manitoba. Soc. Indic. Res. 2012, 106, 213-238. [CrossRef]

10. Gericke, N.; Boeve-de Pauw, J.; Berglund, T.; Olsson, D. The Sustainability Consciousness Questionnaire: The theoretical development and empirical validation of an evaluation instrument for stakeholders working with sustainable development. Sustain. Dev. 2019, 27, 35-49. [CrossRef]

11. United States National Research Council. Science \& Engineering Indicators. 2016. Available online: https://www.nsf.gov/statistics/2016/nsb20161/uploads/1/12/chapter-2.pdf (accessed on 15 March 2020).

12. Terenzini, P.T.; Reason, R.D. Parsing the first year of college: Rethinking the effects of college on students. In Proceedings of the Annual Conference of the Association for the Study of Higher Education, Philadelphia, PA, USA, 19 November 2005. 
13. Al-Naqbi, A.K.; Alshannag, Q. The status of education for sustainable development and sustainability knowledge, attitudes, and behaviors of UAE University students. Int. J. Sustain. High. Educ. 2018, 19, 566-588. [CrossRef]

14. Liu, X.; Zou, Y.; Wu, J. Factors Influencing Public-Sphere Pro-Environmental Behavior among Mongolian College Students: A Test of Value-Belief-Norm Theory. Sustainability 2018, 10, 1384. [CrossRef]

15. Ro, H.K.; Loya, K.I. The Effect of Gender and Race Intersectionality on Student Learning Outcomes in Engineering. Rev. High. Educ. 2015, 38, 359-396. [CrossRef]

16. Ro, H.K.; Knight, D.B. Gender Differences in Learning Outcomes from the College Experiences of Engineering Students. J. Eng. Educ. 2016, 105, 478-507. [CrossRef]

17. Olsson, D.; Gericke, N. The effect of gender on students' sustainability consciousness: A nationwide Swedish study. J. Environ. Educ. 2017, 48, 357-370. [CrossRef]

18. Astin, A.W. Assessment for Excellence: The Philosophy and Practice of Assessment and Evaluation in Higher Education; The Oryx Press: Phoenix, AZ, USA, 1993.

19. Reason, R.D.; Terenzini, P.T.; Domingo, R.J. First Things First: Developing Academic Competence in the First Year of College*. Res. High. Educ. 2006, 47, 149-175. [CrossRef]

20. Reason, R.D.; Terenzi, P.T.; Domingo, R.J. Developing Social and Personal Competence in the First Year of College. Rev. High. Educ. 2007, 30, 271-299. [CrossRef]

21. National Academy of Engineering. The Engineer of 2020: Visions of Engineering in the New Century; Academics Press: Washington DC, WA, USA, 2004.

22. Knight, D.B. Reversing the Logic: An Outcomes-Based Student Typology for Determining "What Works" in Promoting an Array of Engineering-Related Student Learning Outcomes. Educ. Eval. Policy Anal. 2014, 36, 145-169. [CrossRef]

23. Knight, D.B.; Novoselich, B.J. Curricular and Co-curricular Influences on Undergraduate Engineering Student Leadership. J. Eng. Educ. 2017, 106, 44-70. [CrossRef]

24. Carter, D.F.; Ro, H.K.; Alcott, B.; Lattuca, L.R. Co-Curricular Connections: The Role of Undergraduate Research Experiences in Promoting Engineering Students' Communication, Teamwork, and Leadership Skills. Res. High. Educ. 2016, 57, 363-393. [CrossRef]

25. Lattuca, L.R.; Knight, D.B.; Ro, H.K.; Novoselich, B.J. Supporting the Development of Engineers' Interdisciplinary Competence. J. Eng. Educ. 2017, 106, 71-97. [CrossRef]

26. Finelli, C.J.; Holsapple, M.A.; Ra, E.; Bielby, R.M.; Burt, B.A.; Carpenter, D.D.; Harding, T.S.; Sutkus, J.A. An Assessment of Engineering Students' Curricular and Co-Curricular Experiences and Their Ethical Development. J. Eng. Educ. 2012, 101, 469-494. [CrossRef]

27. Klotz, L.; Potvin, G.; Godwin, A.; Cribbs, J.; Hazari, Z.; Barclay, N. Sustainability as a Route to Broadening Participation in Engineering. J. Eng. Educ. 2014, 103, 137-153. [CrossRef]

28. Berglund, T.; Gericke, N.; Chang Rundgren, S.N. The implementation of education for sustainable development in Sweden: Investigating the sustainability consciousness among upper secondary students. Res. Sci. Technol. Educ. 2014, 32, 318-339. [CrossRef]

29. Kollmuss, A.; Agyeman, J. Mind the Gap: Why do people act environmentally and what are the barriers to pro-environmental behavior? Environ. Educ. Res. 2002, 8, 239-260. [CrossRef]

30. Bandura, A. Human agency in social cognitive theory. Am. Psychol. 1989, 44, 1175-1184. [CrossRef]

31. Shealy, T.; Godwin, A.; Gardner, H. Survey Development to Measure the Gap Between Student Awareness, Literacy, and Action to Address Human-caused Climate Change. In Proceedings of the 2017 ASEE Annual Conference \& Exposition, Columbus, OH, USA, 25-28 June 2017.

32. Pascarella, E.T.; Terenzini, P.T. How College Affects Students: Findings and Insights from Twenty Years of Research; Jossey-Bass: San Francisco, CA, USA, 1991.

33. Pascarella, E.T.; Terenzini, P.T. How College Affects Students: A Third Decade of Research; Jossey-Bass: San Francisco, CA, USA, 2005; Volume 2.

34. Matthew, M.J.; Rockenbach, A.N.; Bowman, N.A.; Seifert, T.A.; Wolniak, G.C. How College Affects Students: 21st Century Evidence that Higher Education Works; Jossey-Bass: San Francisco, CA, USA, 2016.

35. Astin, A.W. Student involvement: A developmental theory for higher education. J. Coll. Stud. Dev. 1999, $40,518-529$. 
36. Verdin, D.; Godwin, A. Exploring Latina First-generation College Students' Multiple Identities, Self-efficacy, and Institutional Integration to Inform Achievement in Engineering. J. Women Minor. Sci. Eng. 2018, 24, 261-290. [CrossRef]

37. Bandura, A. Social Cognitive Theory: An Agentic Perspective. Annu. Rev. Psychol. 2001, 52, 1-26. [CrossRef] [PubMed]

38. Sawitri, D.R.; Hadiyanto, H.; Hadi, S.P. Pro-environmental behavior from a socialcognitive theory perspective. Procedia Environ. Sci. 2015, 23, 27-33. [CrossRef]

39. Ro, H.K.; Knight, D.B.; Loya, K.I. Exploring the Moderating Effects of Race and Ethnicity on the Relationship between Curricular and Classroom Experiences and Learning Outcomes in Engineering. J. Women Minor. Sci. Eng. 2016, 22, 91-118. [CrossRef]

40. Ro, H.K.; Kim, S. College Experiences and Learning Outcomes of Women of Color Engineering Students in the United States. Int. J. Gend. Sci. Technol. 2019, 11, 56-82.

41. Lattuca, L.R.; Stark, J.S. Shaping the College Curriculum: Academic Plans in Context; Jossey-Bass: San Francisco, CA, USA, 2009.

42. Ceulemans, K.; De Prins, M. Teacher's manual and method for SD integration in curricula. J. Clean. Prod. 2010, 18, 645-651. [CrossRef]

43. Shing, C.K.; Mohamad, Z.F.; Aziz, A.; Raman, A. Integrating Components of Sustainability into Chemical Engineering Curricula. Int. J. Eng. Educ. 2016, 32, 2653-2664.

44. Kennedy, C.; Hyde, R.; Karney, B. Development of environmental knowledge and attitudes in engineering students. Bull. Sci. Technol. Soc. 2002, 22, 460-473. [CrossRef]

45. Kuo, S.Y.; Jackson, N.L. Influence of an environmental studies course on attitudes of undergraduates at an engineering university. J. Environ. Educ. 2014, 45, 91-104. [CrossRef]

46. Bielefeldt, A.R. Incorporating a sustainability module into first-year courses for civil and environmental engineering students. J. Prof. Issues Eng. Educ. Pract. 2011, 137, 78-85. [CrossRef]

47. Tang, K.H.D. Correlation between sustainability education and engineering students' attitudes towards sustainability. Int. J. Sustain. High. Educ. 2018, 19, 459-472. [CrossRef]

48. Pizmony, O.; Ostrow, J. Pro-Environmental Attitudes and Behaviors in Higher Education: Investigating the Role of Formal and Informal Factors; Research Report; International and Transcultural Studies Unit, Columbia University: New York, NY, USA, 2018.

49. Lozano, R.; Merrill, M.Y.; Sammalisto, K.; Ceulemans, K.; Lozano, F.J. Connecting competences and pedagogical approaches for sustainable development in higher education: A literature review and framework proposal. Sustainability 2017, 9, 1889. [CrossRef]

50. Biggs, J.; Tang, C. Teaching for Quality Learning at University; McGraw Hill Education \& Open University Press: Maidenhead, UK, 2007.

51. Segalàs, J.; Ferrer-Balas, D.; Mulder, K.F. What do engineering students learn in sustainability courses? The effect of the pedagogical approach. J. Clean. Prod. 2010, 18, 275-284. [CrossRef]

52. Jollands, M.; Parthasarathy, R. Developing engineering students' understanding of sustainability using project based learning. Sustainability 2013, 5, 5052-5066. [CrossRef]

53. Yusof, K.M.; Sadikin, A.N.; Phang, F.A.; Aziz, A.A. Instilling professional skills and sustainable development through problem-based learning (PBL) among first year engineering students. Int. J. Eng. Educ. 2016, 32, 333-347.

54. Potvin, G.; Hazari, Z.; Klotz, L.; Godwin, A.; Lock, R.M.; Cribbs, J.D.; Barclay, N. Disciplinary Differences in Engineering Students' Aspirations and Self-Perceptions. In Proceedings of the 2013 ASEE Annual Conference \& Exposition, Atlanta, GA, USA, 23-26 June 2013.

55. Prybutok, A.; Patrick, A.D.; Borrego, M.J.; Seepersad, C.C. Cross-sectional survey study of undergraduate engineering identity. In Proceedings of the 2016 ASEE Annual Conference \& Exposition, New Orleans, LA, USA, 26-29 June 2016.

56. Godwin, A.; Potvin, G.; Hazari, Z. The Development of Critical Engineering Agency, Identity, and the Impact on Engineering Career Choices. In Proceedings of the 2013 ASEE Annual Conference \& Exposition, Atlanta, GA, USA, 23-26 June 2013.

57. Horvath, P. Agency and social adaptation. Appl. Behav. Sci. Rev. 1998, 6, 137-154. [CrossRef]

58. Sampaio, A.R.; Thomas, R.; Font, X. Why are Some Engaged and Not Others? Explaining Environmental Engagement among Small Firms in Tourism. Int. J. Tour. Res. 2012, 14, 235-249. [CrossRef] 
59. Godwin, A.; Potvin, G.; Hazari, Z.; Lock, R. Identity, Critical Agency, and Engineering: An Affective Model for Predicting Engineering as a Career Choice. J. Eng. Educ. 2016, 105, 312-340. [CrossRef]

60. Verdín, D.; Godwin, A.; Klotz, L. Exploring the Sustainability-Related Career Outcome Expectations of Community College Students Interested in Science and Engineering Careers. Community Coll. J. Res. Pract. 2020, 44, 83-98. [CrossRef]

61. Missimer, M.; Connell, T. Pedagogical approaches and design aspects to enable leadership for sustainable development. Sustainability 2012, 5, 172-181. [CrossRef]

62. Cebrián, G.; Junyent, M. Competencies in Education for Sustainable Development: Exploring the Student Teachers' Views. Sustainability 2015, 7, 2768-2786. [CrossRef]

63. Godwin, A.; Potvin, G. Pushing and pulling Sara: A case study of the contrasting influences of high school and university experiences on engineering agency, identity, and participation. J. Res. Sci. Teach. 2017, 54, 439-462. [CrossRef]

64. Baugher, B.; Shealy, T.; Iorio, J.; Knight, D. Impact of International Service Learning on Macro-Ethics: A National Study of Senior Engineering Students. Int. J. Serv. Learn. Eng. 2019, 14, 1-15.

65. De Welde, K.; Laursen, S. The glass obstacle course: Informal and formal barriers for women Ph. D. students in STEM fields. Int. J. Gend. Sci. Technol. 2011, 3, 571-595.

66. Abramo, G.; D’Angelo, C.A.; Murgia, G. Gender differences in research collaboration. J. Informetr. 2013, 7, 811-822. [CrossRef]

67. Liu, X.; Zou, Y.; Ma, Y.; Gao, W. What affects PhD student creativity in China? A case study from the Joint Training Pilot Project. High. Educ. 2019, 1-20. [CrossRef]

68. Pawley, A.L.; Schimpf, C.; Nelson, L. Gender in Engineering Education Research: A Content Analysis of Research in JEE, 1998-2012. J. Eng. Educ. 2016, 105, 508-528. [CrossRef]

69. Meinzen-Dick, R.; Kovarik, C.; Quisumbing, A.R. Gender and Sustainability. Annu. Rev. Environ. Resour. 2014, 39, 29-55. [CrossRef]

70. Michel, J.O. An assessment of teaching and learning about sustainability across the higher education curriculum. Environ. Educ. Res. 2019, 25, 1806-1807. [CrossRef]

71. Olsson, D.; Gericke, N.; Boeve-de Pauw, J.; Berglund, T.; Chang, T. Green schools in Taiwan - Effects on student sustainability consciousness. Glob. Environ. Chang. 2019, 54, 184-194. [CrossRef]

72. Kline, R.B. Principles and Practice of Structural Equation Modeling, 3rd ed.; Guilford Press: New York, NY, USA, 2011.

73. Anderson, J.C.; Gerbing, D.W. Structural equation modeling in practice: A review and recommended two-step approach. Psychol. Bull. 1988, 103, 411-423. [CrossRef]

74. Wu, M. Structural Equation Model: Operation and Application of AMOS; Chongqing University Press: Chongqing, China, 2009.

75. Preacher, K.J.; Hayes, A.F. Asymptotic and resampling strategies for assessing and comparing indirect effects in multiple mediator models. Behav. Res. Methods 2008, 40, 879-891. [CrossRef]

76. Steenkamp, J.E.M.; Baumgartner, H. Assessing Measurement Invariance in Cross-National Consumer Research. J. Consum. Res. 1998, 25, 78-107. [CrossRef]

77. Podsakoff, P.M.; MacKenzie, S.B.; Lee, J.-Y.; Podsakoff, N.P. Common method biases in behavioral research: A critical review of the literature and recommended remedies. J. Appl. Psychol. 2003, 88, 879-903. [CrossRef] [PubMed]

78. Nunnally, J.C. Psychometric Theory, 2nd ed.; McGraw-Hill: New York, NY, USA, 1978.

79. Wu, M. Structural Equation Modeling: Tips for Practical Application; Chongqing University Press: Chongqing, China, 2013.

80. Fornell, C.; Larcker, D.F. Evaluating Structural Equation Models with Unobservable Variables and Measurement Error. J. Mark. Res. 1981, 18, 39-50. [CrossRef]

81. Augustus-Horvath, C.L.; Tylka, T.L. A Test and Extension of Objectification Theory as It Predicts Disordered Eating: Does Women's Age Matter? J. Couns. Psychol. 2009, 56, 253-265. [CrossRef]

82. Ryu, H.C.; Brody, S.D. Examining the impacts of a graduate course on sustainable development using ecological footprint analysis. Int. J. Sustain. High. Educ. 2006, 7, 158-175. [CrossRef]

83. Astin, A.W. Diversity and Multiculturalism on the Campus. Chang. Mag. High. Learn. 1993, $25,44-49$. [CrossRef] 
84. Stern, P.C. New Environmental Theories: Toward a Coherent Theory of Environmentally Significant Behavior. J. Soc. Issues 2000, 56, 407-424. [CrossRef]

85. Erskine, L.; Johnson, S.D. Effective Learning Approaches for Sustainability: A Student Perspective. J. Educ. Bus. 2012, 87, 198-205. [CrossRef]

86. Herranen, J.; Vesterinen, V.-M.; Aksela, M. From Learner-Centered to Learner-Driven Sustainability Education. Sustainability 2018, 10, 2190. [CrossRef]

87. Rydhagen, B.; Dackman, C. Integration of sustainable development in sanitary engineering education in Sweden. Eur. J. Eng. Educ. 2011, 36, 87-95. [CrossRef]

88. Bieri Buschor, C.; Berweger, S.; Keck Frei, A.; Kappler, C. Majoring in STEM-What Accounts for Women's Career Decision Making? A Mixed Methods Study. J. Educ. Res. 2014, 107, 167-176. [CrossRef]

89. Shuman, L.J.; Besterfield-Sacre, M.; McGourty, J. The ABET “Professional Skills"—Can They Be Taught? Can They Be Assessed? J. Eng. Educ. 2005, 94, 41-55. [CrossRef]

90. Luthans, F. The need for and meaning of positive organizational behavior. J. Organ. Behav. 2002, 23, 695-706. [CrossRef]

(C) 2020 by the authors. Licensee MDPI, Basel, Switzerland. This article is an open access article distributed under the terms and conditions of the Creative Commons Attribution (CC BY) license (http://creativecommons.org/licenses/by/4.0/). 